Article

\title{
A Step towards Sustainable Self-Compacting Concrete by Using Partial Substitution of Wheat Straw Ash and Bentonite Clay Instead of Cement
}

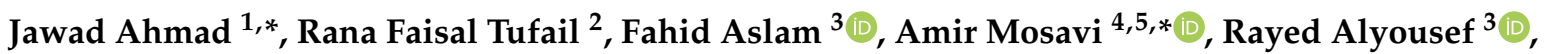 \\ Muhammad Faisal Javed ${ }^{6} \oplus$, Osama Zaid ${ }^{1}$ and Muhammad Sohaib Khan Niazi ${ }^{7}$ \\ 1 Department of Civil Engineering, Swedish College of Engineering and Technology, \\ Wah Cantt 47040, Pakistan; osamazaidmarwat@gmail.com \\ 2 Department of Civil Engineering, Comsats University Islamabad, Wah Campus 47040, Pakistan; \\ faisal.tufail@ciitwah.edu.pk \\ 3 Department of Civil Engineering, College of Engineering in Al-Kharj, Prince Sattam Bin Abdulaziz University, \\ Al-Kharj 11942, Saudi Arabia; f.aslam@psau.edu.sa (F.A.); r.alyousef@psau.edu.sa (R.A.) \\ 4 Faculty of Civil Engineering, Technische Universität Dresden, 01069 Dresden, Germany \\ 5 Neumann Faculty of Informatics, Obuda University, 1034 Budapest, Hungary \\ 6 Department of Civil Engineering, Comsats University Islamabad, Abbottabad Campus, \\ Abbottabad 22010, Pakistan; arbabfaisal@cuiatd.edu.pk \\ 7 Civil Engineering Department, Qurtuba University of Science and Information Technology, \\ Di Khan 29050, Pakistan; sohaibniazi@qurtuba.edu.pk \\ * Correspondence: jawadcivil13@scetwah.edu.pk (J.A.); amir.mosavi@mailbox.tu-dresden.de (A.M.)
}

\section{check for} updates

Citation: Ahmad, J.; Tufail, R.F.; Aslam, F.; Mosavi, A.; Alyousef, R.; Faisal Javed, M.; Zaid, O.; Khan Niazi, M.S. A Step towards Sustainable Self-Compacting Concrete by Using Partial Substitution of Wheat Straw Ash and Bentonite Clay Instead of Cement. Sustainability 2021, 13, 824 https://doi.org/10.3390/su13020824

Received: 28 December 2020 Accepted: 11 January 2021 Published: 15 January 2021

Publisher's Note: MDPI stays neutral with regard to jurisdictional clai$\mathrm{ms}$ in published maps and institutional affiliations.

Copyright: (C) 2021 by the authors. Licensee MDPI, Basel, Switzerland. This article is an open access article distributed under the terms and conditions of the Creative Commons Attribution (CC BY) license (https:// creativecommons.org/licenses/by/ $4.0 /)$.

\begin{abstract}
Self-compacting concrete (SCC) is a special type of concrete that is highly flowable, nonsegregating and spread into place by its own weight, completely filling the formwork even in the presence of dense reinforcement and then encapsulating the rebar without the need for any additional compaction. This research was carried out to evaluate the effects of bentonite clay and wheat straw ash as a partial substitution for cement in SSC. Bentonite clay and wheat straw ash were added in proportion of $0 \%, 5.0 \%, 10 \%, 15 \%$, and $20 \%$ of the weight of the cement. Fresh characteristics were evaluated based on its passing ability and flowability using slump flow, slump T50, L-box, and V-funnel tests. After 7 days, 14 days, and 28 days of curing, cylinders of standard size were cast and tested for compressive and split tensile strength. The test results indicate that bentonite clay and wheat straw ash decrease the passing ability and filling ability of SCC. Furthermore, the concrete specimens' tests indicate that wheat straw ash and bentonite clay additions of up to $10 \%$ and $15 \%$ of the weight of the cement tend to improve the compressive and split tensile strength of hardened SCC. Response surface methodology (statistical models) is used to optimize the combined dosage of wheat straw ash and bentonite clay and is verified through experimental tests. It can also be suggested that bentonite and wheat straw ash are successfully neutralized in concrete instead of cement.
\end{abstract}

Keywords: bentonite clay; wheat straw ash; compressive strength; flowing passing and filling ability; slump cone and slump T50

\section{Introduction}

Self-compacting concrete (SCC) is a special concrete which is highly flowable, nonsegregating and spreads into place by its own weight, completely filling the formwork even in the presence of dense reinforcement [1]. The concept of self-compacting concrete (SCC) was proposed in 1986 by Hajime Okamura [2]; however, the prototype was first developed in Japan in 1988 by Ozawa [3]. Concrete is the most widely used construction material in construction industry all over the world because of its high stability and compressive strength [4]. However, current usage of concrete is unsuitable because it consumes large quantities of fine and coarse aggregates, leading to the depletion of natural 
resources. Not only this, but a billion tons of cement are produced every year, leading to environmental pollution due to the emission of a large quantity of carbon dioxide during the manufacturing process.

The relationship between construction and sustainability has become crucial in the engineering sector, and different beliefs have recently appeared in the construction industry relating to minimizing the effect of construction on the environment [5]. The cement business is fronting threats such as the rising costs of energy delivery as well as lessening $\mathrm{CO} 2$ emissions and ensuring the delivery of unrefined materials of adequate quality [6]. The worldwide production of cement is projected to increase constantly from 1990 to 2050. This was expected because cement is the most consumed product on Earth after water. The industry is rapidly rising, especially in developing countries like China and India that have a high need for cement for housing and infrastructure [7].

Last year, Pakistan produced 41.14 million tons of cement according to the International Cement Review [8], as shown in Figure 1. The country's cement industry has already built the capacity to produce 59.5 million tons of cement in anticipation of future demand for housing and infrastructure [9]. Keeping in view these concerns about the environment, the cost of materials for construction, a shortage of raw materials, and the higher energy demand, the practice of utilizing alternate materials for construction is becoming a common concern across the globe [10].

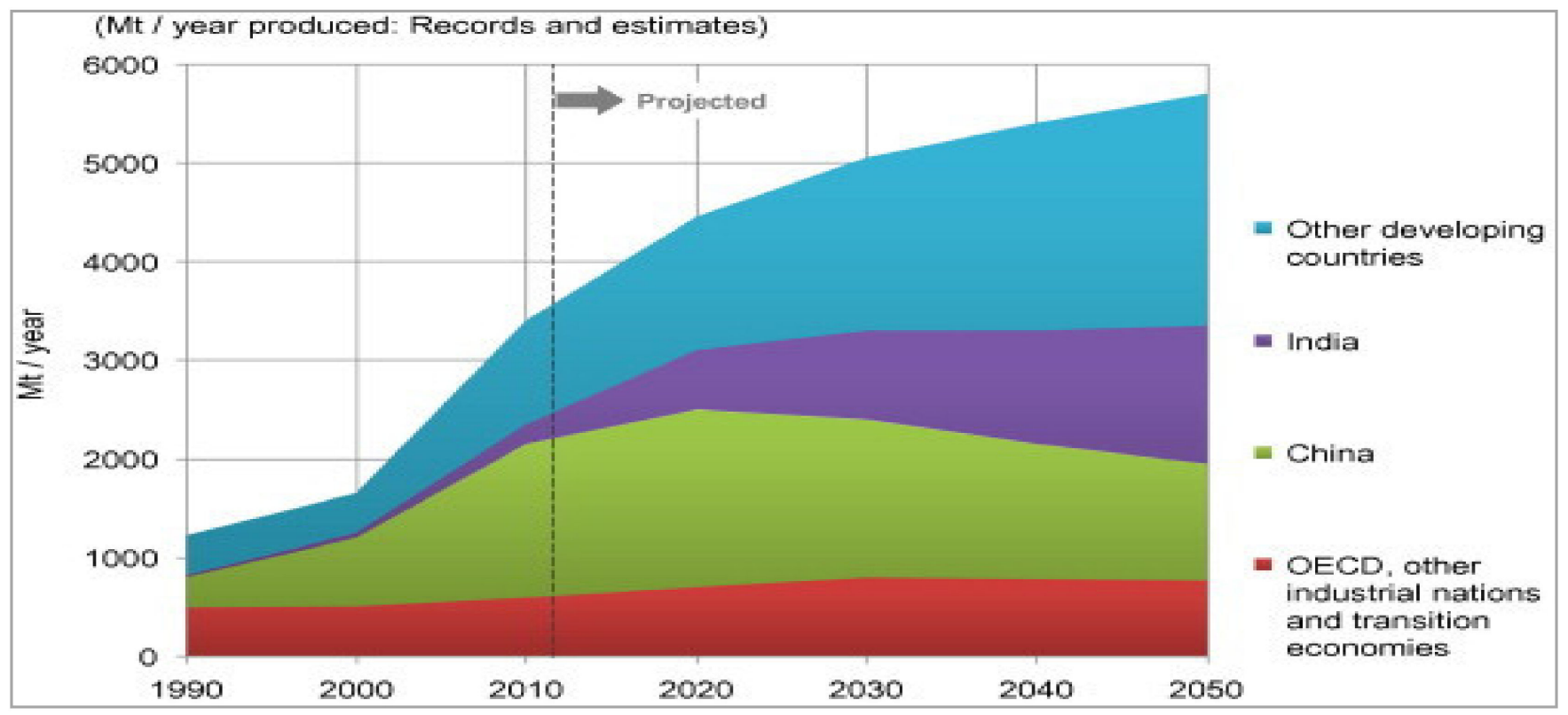

Figure 1. World cement production, 1990-2050.

The particular focus of this research was on the partial use of wheat straw ash and bentonite clay instead of cement. It is suggested by researchers that the consumption of supplementary cementitious materials in concrete helps to reduce the adverse environmental effects related to the manufacturing process of cement or concrete [11]. With the utilization of these waste products as supplementary and replacement materials, there is considerable energy conservation and a reduction in the consumption of cement, which aids in the reduction of the release of carbon dioxide into the environment [12]. Moreover, there could be considerable improvement in the strength and durability properties with the use of supplementary cementing materials in concrete. Therefore, wide-ranging research has been carried out on a number of supplementary materials, such as rice husk ash, metakaolin ash, sewage sludge ash, and palm shale oil. [13].

Bentonite clay occurs in a different area of Khyber Pakhtune Khwa (KPK), Pakistan. It has been reported that one of the bentonite clays originating from Karak, Pakistan is spread over an area of $18 \mathrm{~km}^{2}$ [14]. The chemical reaction between bentonite clay and sand 
produces essential oxides of magnesium $(\mathrm{MgO})$ and potassium $\left(\mathrm{K}_{2} \mathrm{O}\right)$, which are known to improve strength [15]. It has been also reported that bentonite clay can be used for partial substitution of cement for the production of concrete with improved mechanical properties [9].

A major agricultural by-product obtained from cereal production is wheat straw waste, which encourages environmental pollution because farmers burn it in open fields. However, when wheat straw waste is properly burnt under controlled situations, a material that has cementing properties and that can be used in concrete as supplementary cementing material is produced [16]. The successful utilization in the prevailing environment will offer multiple benefits, including the provision of a cost-effective solution to construction industry and reduced environmental and health issues, and it will also have a positive impact on the durability of the system. Several researchers have evaluated the feasibility of using wheat straw ash (WSA) in normal concrete $[9,17,18]$. Research on WSA for partial substation of cement in concrete production was carried out, and a positive influence on concrete performance was reported. However, further research recommended the use of different chemicals or a mineral admixture with WSA in concrete. In the current research, wheat straw ash (WSA) and bentonite clay (BC) with varying doses were incorporated in concrete. Response surface and contour plot were used to optimize the combined effects of wheat straw ash (WSA) and bentonite clay (BC). From the experimental results, it can be concluded that the performance of concrete was improved considerably with the incorporation of bentonite clay in WSA.

\section{Materials and Experimental Program}

\subsection{Materials}

\subsubsection{Cement}

Ordinary Portland cement (OPC) type-1 in accordance with ASTM C150 [19] was used in this study. Its chemical and physical properties are displayed in Table 1.

Table 1. Physical and chemical property of ordinary Portland cement (OPC).

\begin{tabular}{cccc}
\hline Chemical Property & Percentage (\%) & Physical Property & Results \\
\hline $\mathrm{Ca}_{0}$ & 62.7 & Size & $\leq 75 \mu$ \\
$\mathrm{SiO}_{2}$ & 25.9 & Fineness & $92 \%$ \\
$\mathrm{Al}_{2} \mathrm{O}_{3}$ & 8.4 & Normal & $28 \%$ \\
& Consistency & Initial \\
$\mathrm{Fe}_{2} \mathrm{O}_{3}$ & 4.7 & Stetting Time & $38 \mathrm{~min}$ \\
& Final & $412 \mathrm{~min}$ \\
$\mathrm{MgO}$ & 5.5 & Stetting Time & $322 \mathrm{~m}^{2} / \mathrm{kg}$ \\
$\mathrm{SO}$ & 1.9 & Specific surface & $1.70 \%$ \\
$\mathrm{~K}_{2} \mathrm{O}$ & 2.4 & Soundness & 28-day compressive \\
$\mathrm{Na}_{2} \mathrm{O}$ & 0.2 & Strength & $42 \mathrm{Mpa}$ \\
\hline
\end{tabular}

\subsubsection{Fine Aggregate and Coarse Aggregate}

Natural sand was used as a fine aggregate (FA) in all the mixes in the saturated surface dry (SSD) condition, and they were obtained from Larencepur Wah cantt Punjab Pakistan. Normal weight coarse aggregate (crush stone) in the saturated dry condition (SSD) was obtained from Margallah Wah cantt Punjab Pakistan. The nominal maximum size of the coarse aggregate is $12.5 \mathrm{~mm}$. Different tests were performed on the aggregate to evaluate its physical properties, as shown in Table 2. 
Table 2. Physical properties of fine and coarse aggregate.

\begin{tabular}{ccc}
\hline Physical Property & Fine Aggregate & Coarse Aggregate \\
\hline Particle Size & 4.75 to $0.075 \mathrm{~mm}$ & 12.5 to 4.75 \\
Fineness Modulus & 2.93 & 4.7 \\
Absorption Capacity & $5.28 \%$ & $2.13 \%$ \\
Moisture Content & $1.8 \%$ & $1.25 \%$ \\
Bulk density & 1586 & 1535 \\
$\left(\mathrm{~kg} / \mathrm{m}^{3}\right)$ & & \\
\hline
\end{tabular}

\subsubsection{Wheat Straw Ash}

Wheat straw was collected from a local agriculture farm. Then, it was burned at an uncontrolled temperature at the factory. The resultant burn ash was passed through sieve \# 200, which was used for cement replacement in this research. Its chemically properties are shown in Table 3.

Table 3. Chemical composition of wheat straw ash and bentonite clay.

\begin{tabular}{ccc}
\hline Chemical & Wheat Straw Ash (\%) & Bentonite (\%) \\
\hline $\mathrm{Ca}_{0}$ & 12.56 & 9.7 \\
$\mathrm{SiO}_{2}$ & 39.63 & 55.3 \\
$\mathrm{Al}_{2} \mathrm{O}_{3}$ & 24.11 & 25.6 \\
$\mathrm{Fe}_{2} \mathrm{O}_{3}$ & 6.2 & 2.7 \\
$\mathrm{MgO}$ & 3.5 & 3.5 \\
$\mathrm{SO}_{3}$ & 0.61 & 1.3 \\
$\mathrm{~K}_{2} \mathrm{O}$ & 2.09 & 2.7 \\
$\mathrm{Na}_{2} \mathrm{O}$ & 0.049 & 0.4 \\
\hline
\end{tabular}

\subsubsection{Bentonite Clay}

Bentonite clay was collected from kohat, Kpk, Pakistan. After collection, bentonite was transfer to a bill mill machine for grinding to obtain a size lower than $0.075 \mathrm{~mm}$ (passed through sieve \#200). Its chemically properties are shown in Table 3.

\subsubsection{Superplasticizer}

Chemrite-530 used as a superplasticizer because it is a high-range water-reducing admixture that is nontoxic and nonhazardous under relevant health and safety issues. The superplasticizer meets the requirements of EN 934-2 T 3.1/3 [20] and ASTM C-494 Type F [21]. Typical properties of the superplasticizer are given in Table 4.

Table 4. Physical properties of the superplasticizer.

\begin{tabular}{cc}
\hline Property & Result \\
\hline Color & Dark brown \\
Relative density & 1.58 at $27^{\circ} \mathrm{C}$ \\
Chloride content & $<0.2 \%$ \\
Physical state & Liquid \\
\hline
\end{tabular}

\subsection{Experimental Program}

To achieve the goal of project, a two-stage experimental program was developed. In the first stage, trial mixes were prepared in order to achieve the requirement of the technical specification for SCC [1]. In the second stage, six mixes were prepared with varying percentages of WSA and bentonite clay to determine the effects of WSA and bentonite clay on self-compacting concrete (SCC), which were based on the findings of the first stage. The typical acceptance criteria for self-compacting concrete defined by the technical specification of a maximum aggregate size of up to $20 \mathrm{~mm}$ are shown in Table 5 . 
Table 5. Typical acceptance criteria for self-compacting concrete.

\begin{tabular}{ccccc}
\hline Sr. No. & Tests Methods & Unit & Minimum & Maximum \\
\hline 1 & Slump Test & Mm & 600 & 800 \\
2 & T50 Slump Flow & Sec & 2 & 5 \\
3 & L-Box Test & $(\mathrm{H} 2 / \mathrm{H} 1)$ & 0.8 & 1 \\
4 & V-Funnel Tests & Sec & 6 & 12 \\
\hline
\end{tabular}

\subsubsection{Tests and Size of the Specimen}

Fresh properties of SCC such as slump flow, slump T50 spread time, L-box, and Vfunnel were examined according to the technical specification for SCC [1]. A cylinder with of standard size $(6 \times 12 \mathrm{in})$ was used to measure the compressive strength at as per ASTM C39/C39M [22]. Similar cylinders of standard size $(6 \times 12$ in) were cast and tested to find their tensile strength as per ASTM C496-71 [23]. Three specimens were tested for each test at 7, 14 and, 28 days, and the mean value of the specimens was considered its strength.

\subsubsection{Sample Preparation Method}

The ASTM C-31 [24] method was followed for the preparation of the specimens, and compaction was done manually on three layers with 25 blows per layer. Eight mixes were prepared with varying dosages of the superplasticizer. Details of the mixes are provided in Table 6 . Before the mixing process began, the required quantity of material was weighed by the method of weighing. The speed of the mixer was maintained at $35 \mathrm{rev} / \mathrm{min}$ to mix the materials. First, coarse aggregate was added to the mixer and then fine aggregate; both materials were dry mixed. Then, the necessary quantities of cement and water were added with time, and mixing was conducted for about $8 \mathrm{~min}$ for all mixes.

Table 6. Trial mixes of self-compacting concrete (SCC).

\begin{tabular}{ccccccccc}
\hline Materials & Mix 1 & Mix 2 & Mix 3 & Mix 4 & Mix 5 & Mix 6 & Mix 7 & Mix 8 \\
\hline Cement $\left(\mathrm{kg} / \mathrm{m}^{3}\right)$ & 425 & 425 & 425 & 425 & 425 & 425 & 425 & 425 \\
\hline Sand $\left(\mathrm{kg} / \mathrm{m}^{3}\right)$ & 625 & 625 & 625 & 625 & 625 & 625 & 625 & 625 \\
\hline Crush $\left(\mathrm{kg} / \mathrm{m}^{3}\right)$ & 1270 & 1270 & 1270 & 1270 & 1270 & 1270 & 1270 & 1270 \\
\hline water cement ratio & 0.35 & 0.35 & 0.35 & 0.35 & 0.45 & 0.45 & 0.45 & 0.45 \\
\hline Superplasticizer $(\mathrm{kg})$ & - & 2.12 & 4.25 & 6.37 & - & 2.12 & 4.25 & 6.37 \\
\hline
\end{tabular}

\section{Test Results}

\subsection{First Stage Results}

In first stage, eight mixes, as shown in Table 6, were prepared in order to achieve the best possible mix that would fulfil the requirements of the technical specification for SCC. Based on the results, the fresh properties of SCC for each trial mix with different test methods (slump flow, slump T50 spreads, L-box, and V-funnel) are show in Table 7. It is clear from Table 7 that Mix 6 will be satisfied in the range of different tests (slump flow, slump T50 spread time, L-box, and V-funnel) provided by the technical specification for self-compacting concrete, while the other mixes will not satisfy the range of such tests. Therefore, Mix 6 is considered the best mix of self-compacting concrete and can be used as a reference concrete (control) with varying percentages of WSA and bentonite clay. 
Table 7. Results of trial mixes of self-compacting concrete (SCC).

\begin{tabular}{|c|c|c|c|c|c|c|c|c|}
\hline Tests Methods & Mix 1 & Mix 2 & Mix 3 & Mix 4 & $\operatorname{Mix} 5$ & Mix 6 & $\operatorname{Mix} 7$ & Mix 8 \\
\hline Slump (mm) & 535 & 542 & 568 & 622 & 572 & 625 & 710 & 768 \\
\hline L-Box Test (H2/H1) & 0.60 & 0.68 & 0.72 & 0.83 & 0.76 & 0.84 & 0.92 & 0.98 \\
\hline V-Funnel Tests (Sec) & 19 & 16 & 15 & 11 & 14 & 7 & 5 & 3 \\
\hline T50 Slump Flow & 11 & 8 & 7 & 5.2 & 6 & 4.5 & 2.8 & 2.2 \\
\hline $\begin{array}{l}\text { Remarks } \\
\text { as per } \\
\text { EFNARC }\end{array}$ & $\begin{array}{c}\text { Too } \\
\text { Stiff and } \\
\text { Segregation }\end{array}$ & Too Stiff & Small Stiff & $\begin{array}{c}\text { Small } \\
\text { Bleeding }\end{array}$ & $\begin{array}{c}\text { Small } \\
\text { Stiff }\end{array}$ & Good SCC & $\begin{array}{c}\text { Small } \\
\text { Bleeding }\end{array}$ & $\begin{array}{l}\text { Too Much } \\
\text { Bleeding and } \\
\text { Segregation }\end{array}$ \\
\hline
\end{tabular}

\subsection{Second Stage (Mix Proportion of SCC)}

Based on the results of the first stage, Mix 6 (SCC) was selected for further experimental work. Therefore, the second stage of the experimental work was conducted on Mix 6 (SCC) with varying percentages of WSA and $\mathrm{BC}$. Five mixes were prepared during the second stage after achieving the requirement of the technical specification for SCC (Mix 6), which was obtained during the first stage, as shown in Table 8. Different percentages of WSA and $\mathrm{BC}$ were added to the fresh self-compacting concrete (SCC). The percentages of WSA and bentonite clay used were $5 \%, 10 \%, 15 \%$, and $20 \%$ of the weight of the cement. Table 8 shows the concrete mix proportions of SCC (Mix 6) with varying percentages of WSA and bentonite clay.

Table 8. Mix proportion of SCC with varying percentages of wheat straw ash (WSA) and bentonite clay (BC).

\begin{tabular}{cccccc}
\hline Materials & Mix 6 & SCC1 & SCC2 & SCC3 & SCC4 \\
\hline $\begin{array}{c}\text { Cement } \\
\left(\mathrm{kg} / \mathrm{m}^{3}\right)\end{array}$ & 425 & 403.7 & 382.7 & 361.2 & 340 \\
\hline $\begin{array}{c}\text { Sand } / \mathrm{F} . \mathrm{A} \\
\left(\mathrm{kg} / \mathrm{m}^{3}\right)\end{array}$ & 625 & 625 & 625 & 625 & 625 \\
\hline $\begin{array}{c}\text { Crush } / \mathrm{C} . \mathrm{A} \\
\left(\mathrm{kg} / \mathrm{m}^{3}\right)\end{array}$ & 1270 & 1270 & 1270 & 1270 & 1270 \\
\hline W/C & 0.45 & 0.45 & 0.45 & 0.45 & 0.45 \\
\hline $\begin{array}{c}\text { Superplasticizer } \\
(\mathrm{kg})\end{array}$ & 2.12 & 2.12 & 2.12 & 2.12 & 2.12 \\
\hline $\begin{array}{c}\text { Wheat Straw Ash } \\
(\mathrm{kg})\end{array}$ & - & 21.25 & 42.5 & 63.75 & 85 \\
\hline $\begin{array}{c}\text { Bentonite Clay } \\
\mathrm{kg})\end{array}$ & - & 21.25 & 42.5 & 63.75 & 85 \\
\hline
\end{tabular}

\subsubsection{Fresh Properties}

\section{Slump Flow and Slump T50}

The results of the slump flow and slump T50 tests of varying dosages of wheat straw ash (WSA) and bentonite clay are shown in Figures 2 and 3 . The slump flow value decreased as the percentage of wheat straw ash (WSA) increased. The maximum slump flow value was obtaining at $0 \%$ (control) substitution of wheat straw ash, whereas the minimum slump flow value was obtained at $20 \%$ substitution of wheat straw ash. The time required to spread concrete into a diameter of $50 \mathrm{~cm}$ (slump T50) increased as the percentage of wheat straw ash increased from $0 \%$ to $20 \%$ in relation to the weight of the cement, with the maximum time required observed when the substitution rate of wheat straw ash was $20 \%$. The decrease in flowability of SCC due to the incorporation of wheat straw ash can be attributed due to fact that particle shape (flat and elongated) and surface texture (rough), which increase the internal friction between the concrete ingredients, as well as the larger surface area of wheat straw ash result in more water needed for lubrication. Similar findings were reported in previous studies [25]. 


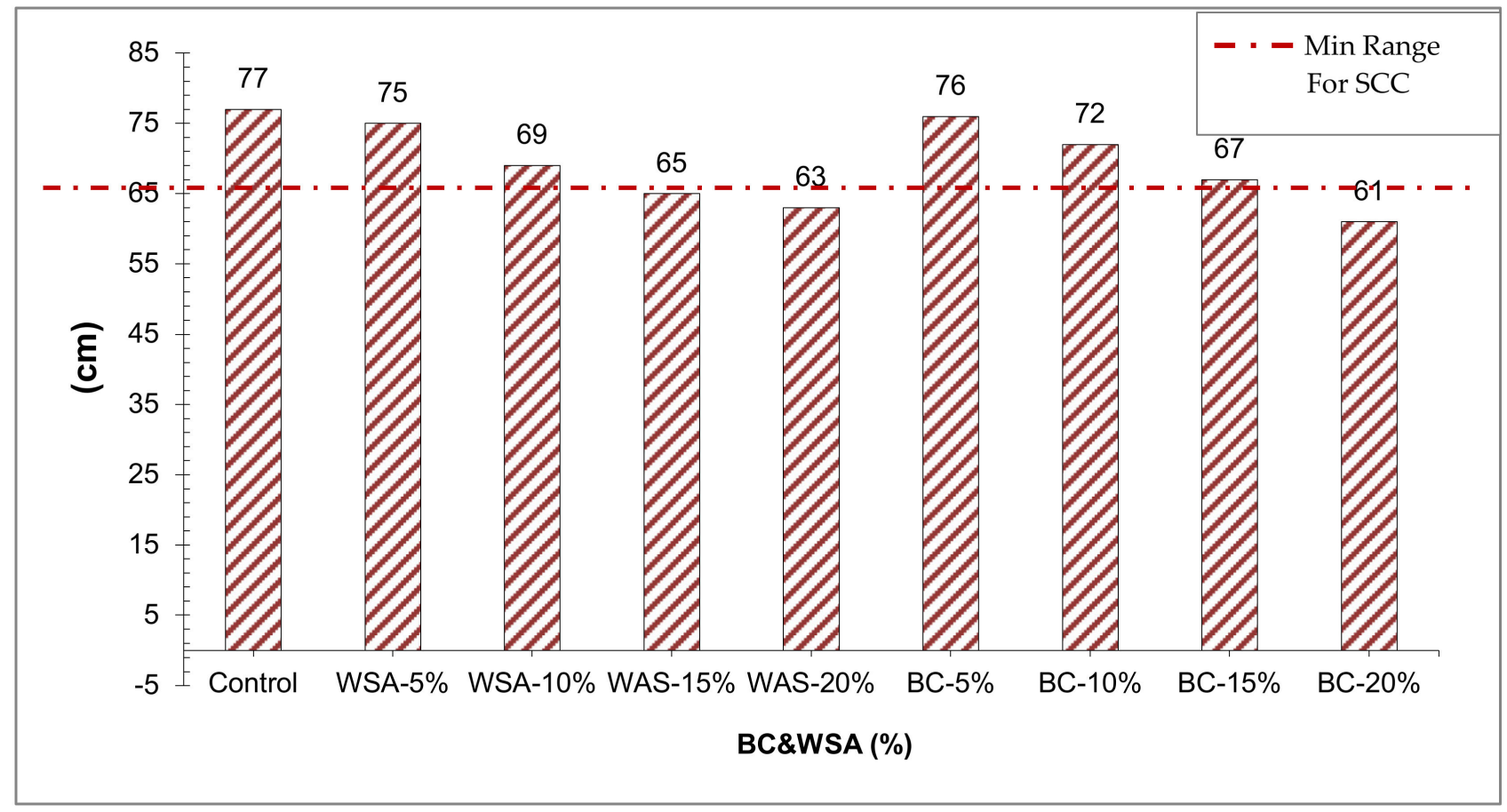

Figure 2. Slump flow test results.

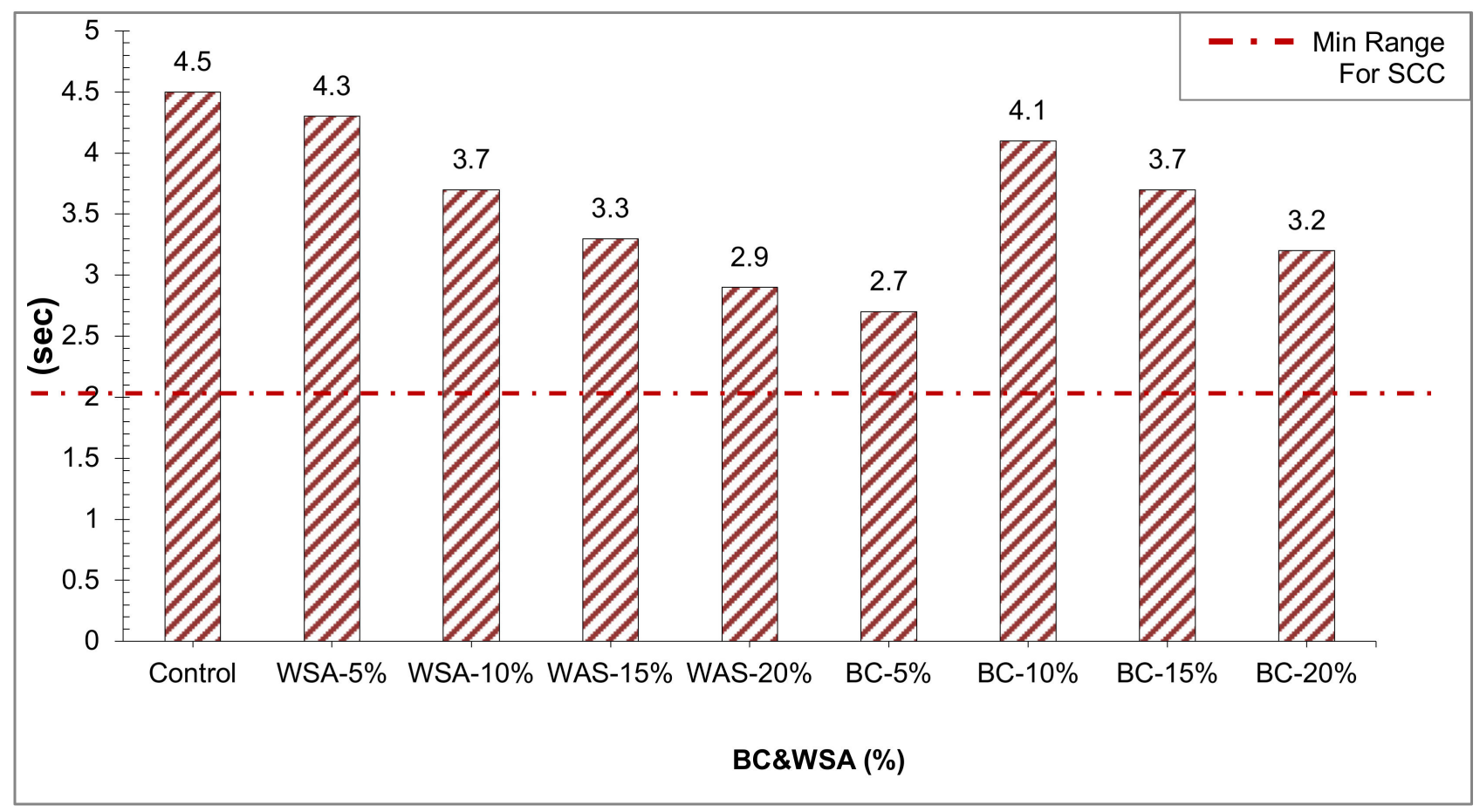

Figure 3. Slump T50 test results.

Regarding bentonite clay, the slump flow value decrease as the percentage of bentonite clay increased. The maximum slump flow was obtaining at $0 \%$ addition of bentonite clay, while the minimum slump flow was observed at $20 \%$ substitution of bentonite clay, as shown in Figure 2.

The slump T50 values increased as the percentage of bentonite clay increased. The maximum slump flow was obtaining at $20 \%$ addition of bentonite clay, while the minimum slump flow was observed at $0 \%$ substitution of bentonite clay, as show in Figure 3. 
When more bentonite clay can be observed in the concrete mix, less water is available for lubrication, and, therefore, the slump flow and slump T50 values decrease [26]. Moreover, due to the larger surface area of bentonite clay, more cement paste is required to reduce the internal friction between the fine and coarse aggregate [27]. The slump flow and slump T50 values of all of the mixes of bentonite clay and wheat straw ash fell within the limits that define the technical specification for self-compacting concrete and showed good filling ability [1].

\section{L-Box and V-Funnel}

The L-box test was used to assess the passing ability of self-consolidating concrete. Like slump flow, the passing ability of concrete decreased as the percentages of bentonite clay increase from $0 \%$ to $20 \%$ in relation to the weight of the cement, and the maximum passing ability was observed with an incorporation rate of $0 \%$, as shown in Figure 4. Regarding wheat straw ash, like slump flow, the passing ability of SCC decreased as the percentages of wheat straw as increased from $0 \%$ to $20 \%$ in relation to the of the cement, as shown in Figure 4. The typical acceptable range of the blocking ratio for good passing ability of SSC is from 0.8 to 1.0 according to the technical specification for SSC. From the results, it can be observed that all of the bentonite clay and wheat straw ash show an L-box ratio between 0.8 to 1.0 , which means that these mixes fall within the limits defined by the technical specification for self-compacting concrete [1]. However, it should be noted that the authors of [28] determined that a 0.60 blocking ratio has been accepted for SCC to achieve good filling ability. According to this standard, if the value of $\mathrm{h} 2 / \mathrm{h} 1$ in the L-box test is greater than 0.8 , the SCC has good passing ability [29].

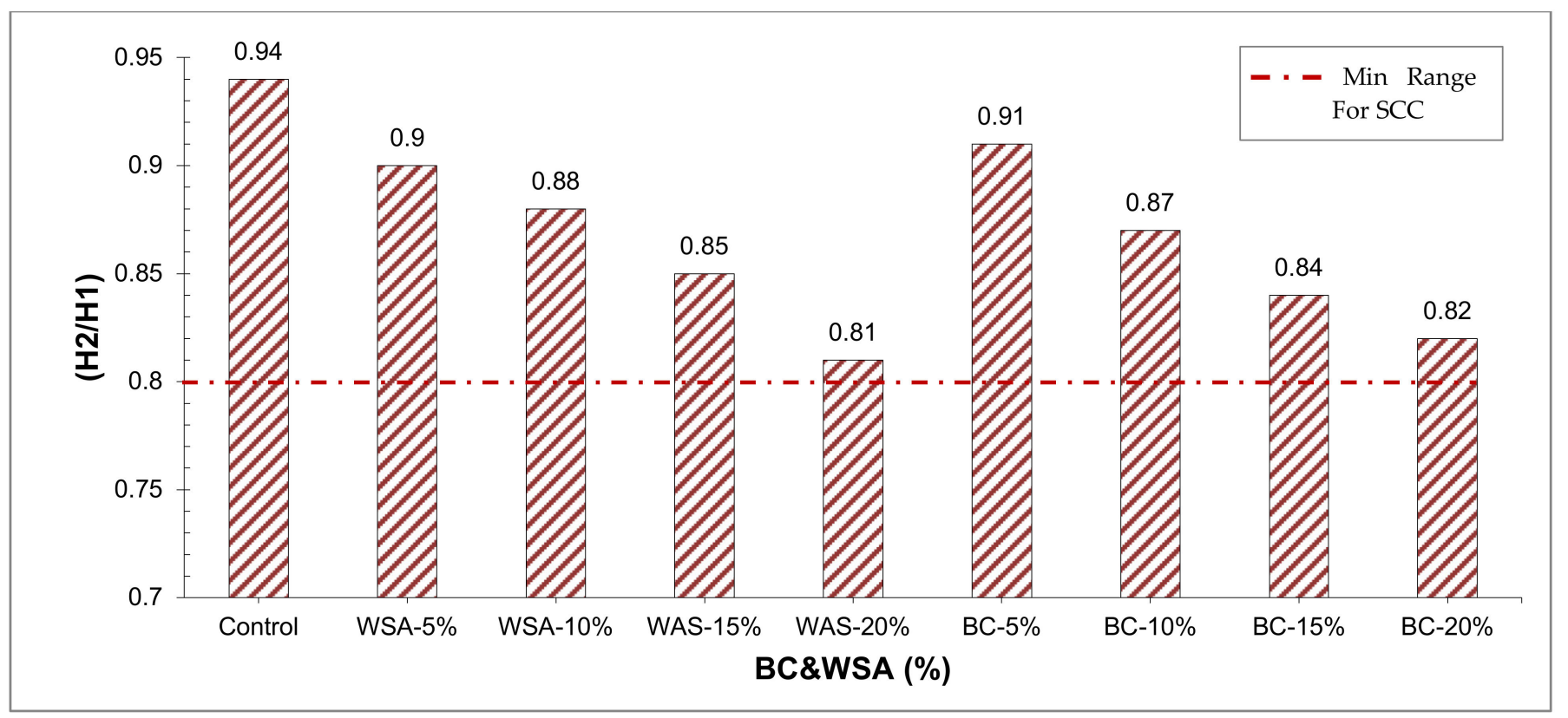

Figure 4. L-box test results.

The V-funnel test was used to check the flow ability of self-compacting concrete. The flow time of the V-funnel tests is used to identify the filling ability of SCC. It measures the ease flow of concrete. A shorter flow time indicates greater flow ability. Similar to the slump flow test, the flow ability of self-compacting concrete decreased as the percentage of bentonite clay and wheat straw ash increased, as shown in Figure 5. The maximum flow ability was obtained when the substitution was $0 \%$, while the minimum flow ability was obtained at $20 \%$ substitution with bentonite clay and wheat straw ash, respectively. All of the mixes showed flow times between 6 and 12 seconds, and they displayed an acceptable range according to the technical specification for SCC [1] and good flowability. 


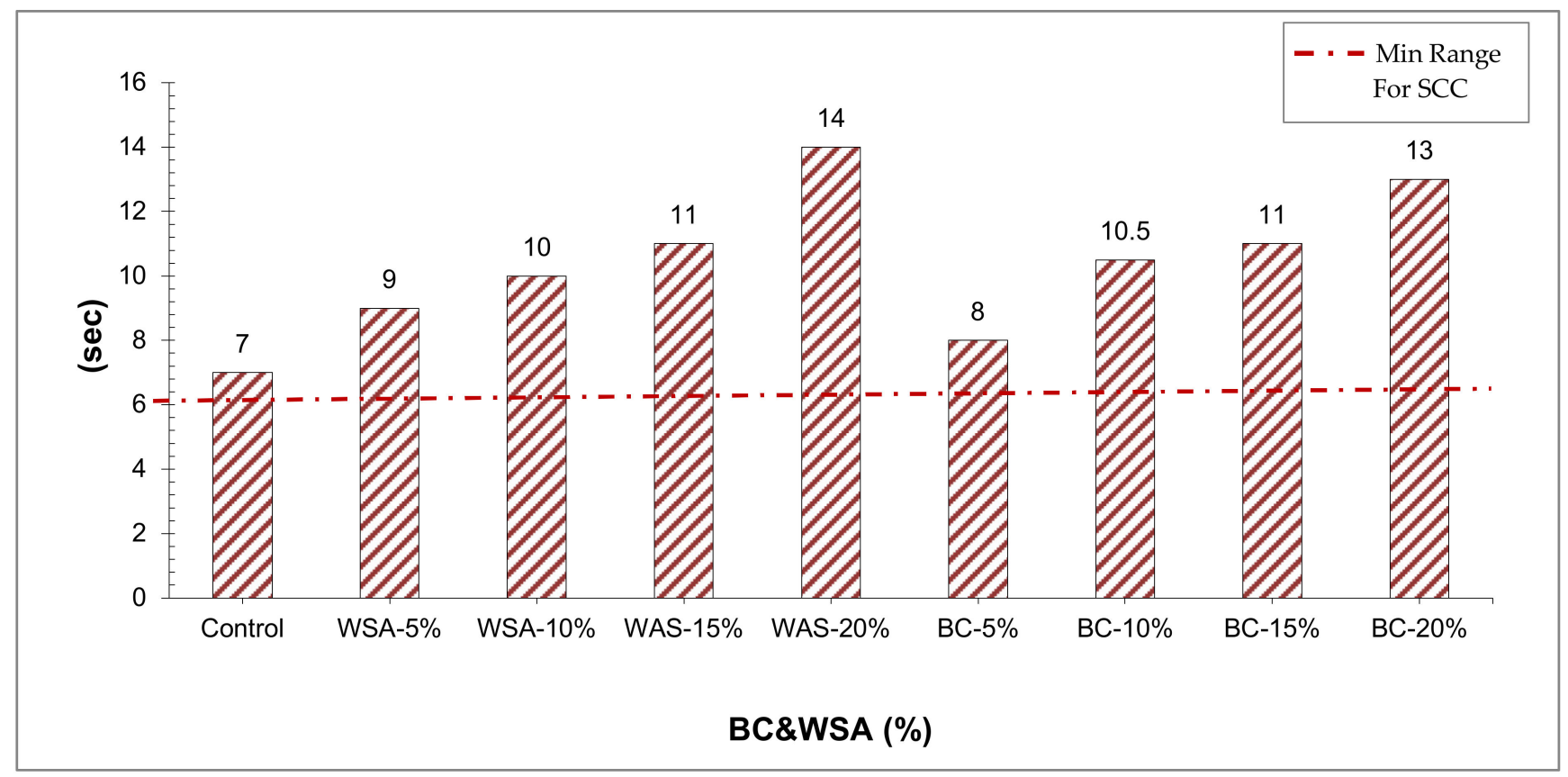

Figure 5. V-funnel test results.

\section{Mechanical Properties}

\subsection{Compressive Strength}

Compressive strength is the capability of a material to resist stresses when it is compressed. The compressive strength test was carried out following the standard ASTM C39/C39M procedure [22] for cylindrical specimens with standard dimensions of 6 inches in diameter and 12 inches in length. In this test, the concrete specimens (cylinders) were exposed to a compressive axial force at a rate within the recommended limit until concrete failure was reached. Compressive strength was then determined from the greatest failure load divided by the X-sectional area of the specimen, as shown in Figure 6.

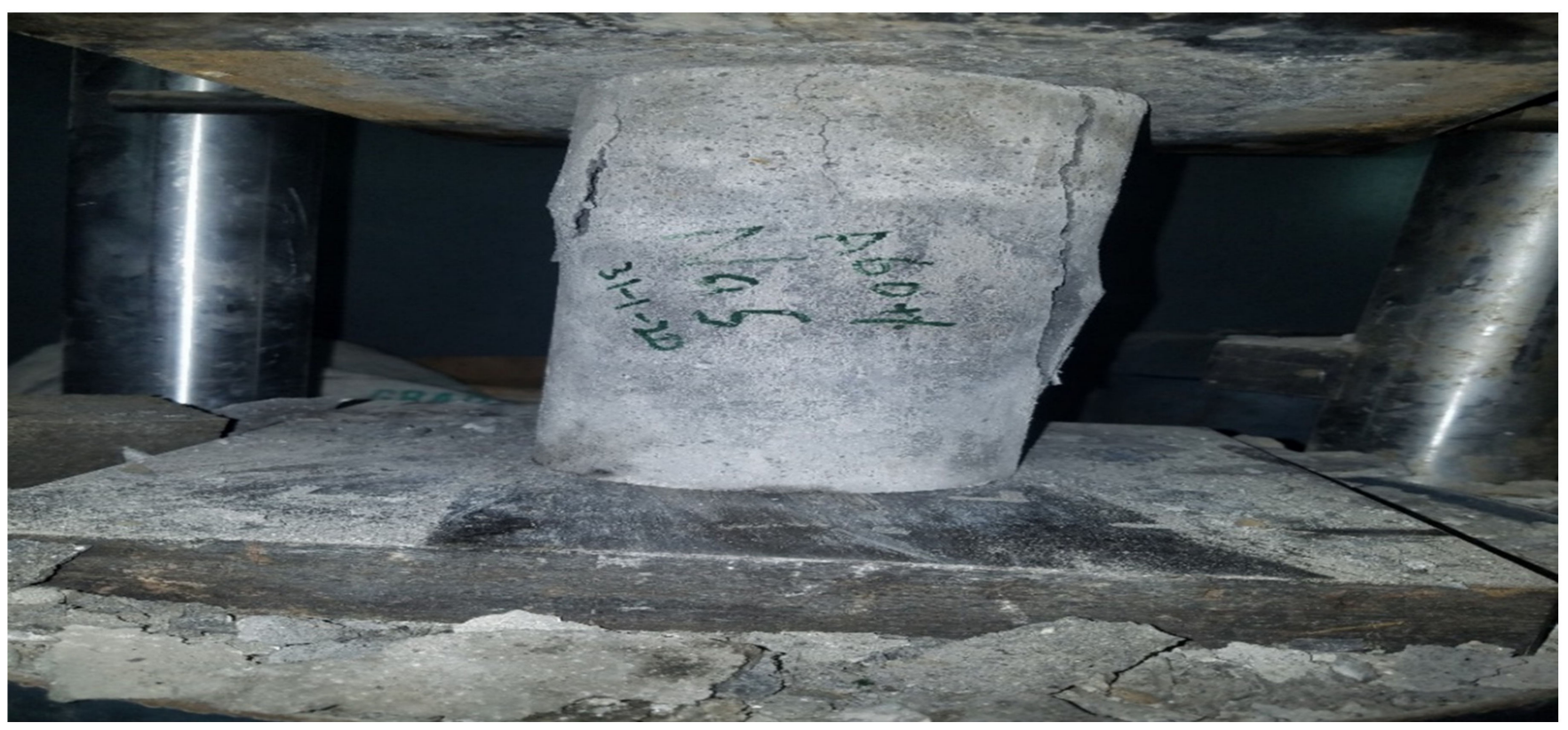

Figure 6. Compressive strength setup. 
Figure 7 shows compressive strength of varying dosages of wheat straw ash and bentonite clay. It can be observed that compressive strength increased as the percentage of wheat straw ash substitution increased by up to $10 \%$ of the weight of the cement and then decreased gradually. In addition, the compressive strength increased with incorporation of the wheat straw ash (WSA) [25]. The highest compressive strength was obtained at a $10 \%$ dosage of WSA as compared to blank or reference concrete. However, beyond the $10 \%$ dosage, the strength decreased. The positive effect on compressive strength is due to the pozzolanic reaction of $\mathrm{SiO}_{2}$ in wheat straw ash (WSA) with Ch of cement producing additional cementitious compounds $[17,25,30]$. The additional binder produced by the wheat straw ash (WSA) reaction with available lime allows wheat straw ash (WSA) concrete to continue to gain strength over time. However, at a higher dosage of wheat straw ash $(20 \%$ of the weight of the cement), the strength decreased due to the dilution effect, which leads to an alkali silica reaction as a result of the higher quantity of unreactive silica available as a consequence of the high quantity of wheat straw ash (WSA). Moreover, at a higher dosage ( $20 \%$ of WSA), the compaction process became more difficult due to the lack of workability, which resulted in porous concrete with lower strength [25]. Therefore, it is recommended that wheat straw ash (WSA) should be used at a substitution level of $10 \%$ of the weight of the cement.

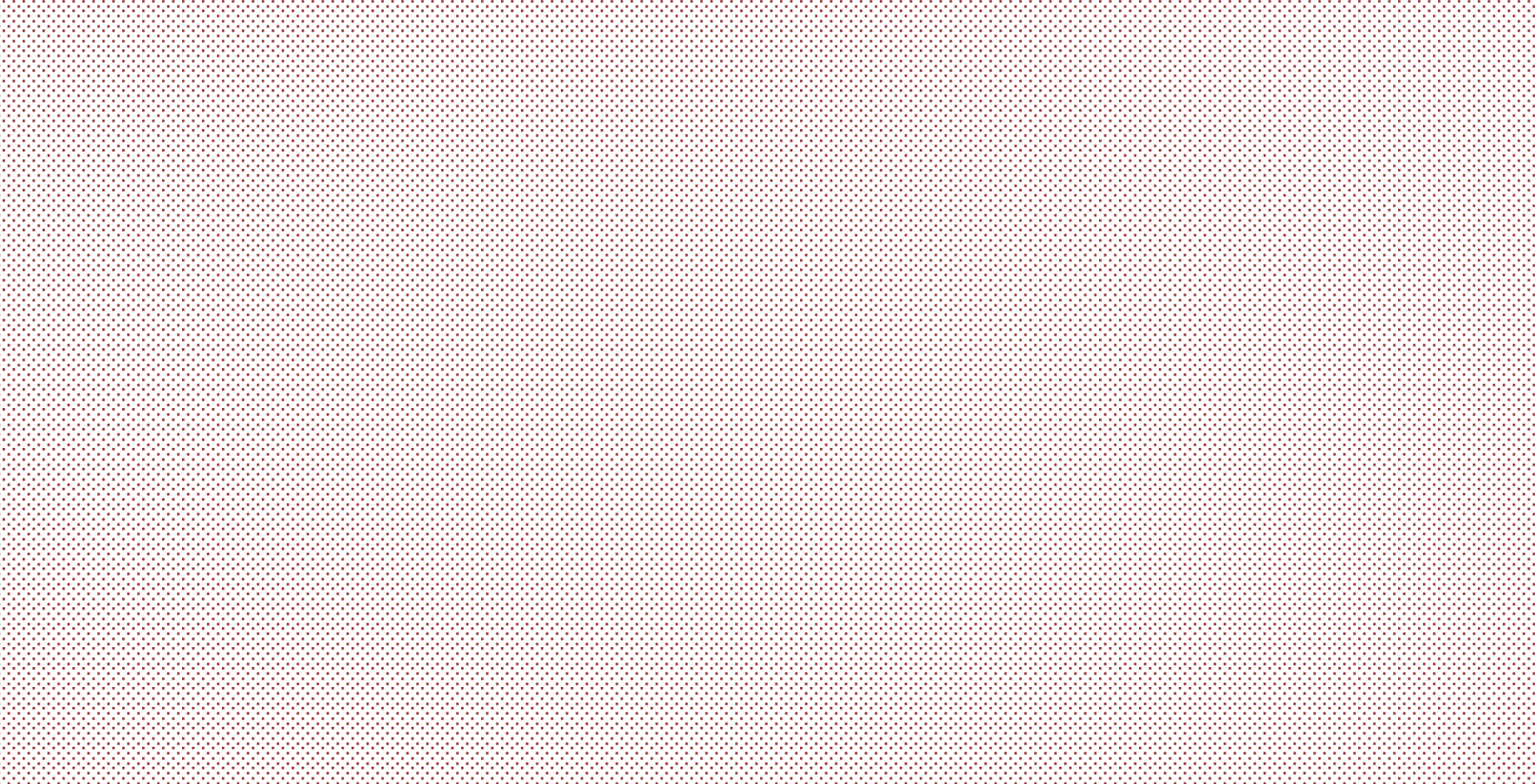

Figure 7. Compressive strength results.

Regarding bentonite clay (BC), it can be observed that compressive strength increased as the substitution percentage of bentonite clay (BC) increased by up to $15 \%$ of the weight of the cement and then decreased gradually, as shown in Figure 7.

It has been also reported that compressive strength increased with the incorporation of bentonite clay (BC) [9]. The highest compressive strength was obtained at a $15 \%$ dosage of bentonite clay $(\mathrm{BC})$ as compared to blank or reference concrete. However, beyond the $15 \%$ dosage, the strength decreased. The positive effect on compressive strength is due to the pozzolanic reaction of $\mathrm{SiO}_{2}$ in bentonite clay (BC) [9] with Ch of cement producing additional cementitious compounds. The additional binder produced by the bentonite clay (BC) reaction with available lime allows bentonite clay (BC) concrete to continue to gain strength over time. However, at higher a dosage of bentonite clay (BC) $(20 \%$ of the total weight of the cement), the strength decreased due to the dilution effect, which leads to 
an alkali silica reaction as a result of the higher quantity of unreactive silica available as a consequence of the high quantity of bentonite clay (BC). Moreover, at a higher dosage of bentonite clay $(\mathrm{BC})$, the compaction process became more difficult due poor workability, resulting in less compressive strength [27].

A relative analysis was carried out in which the 28-day compressive strength of the control mix was considered the reference mix, and from this, different mixes with varying percentages of wheat straw ash and bentonite clay were compared, as shown in Figure 8.

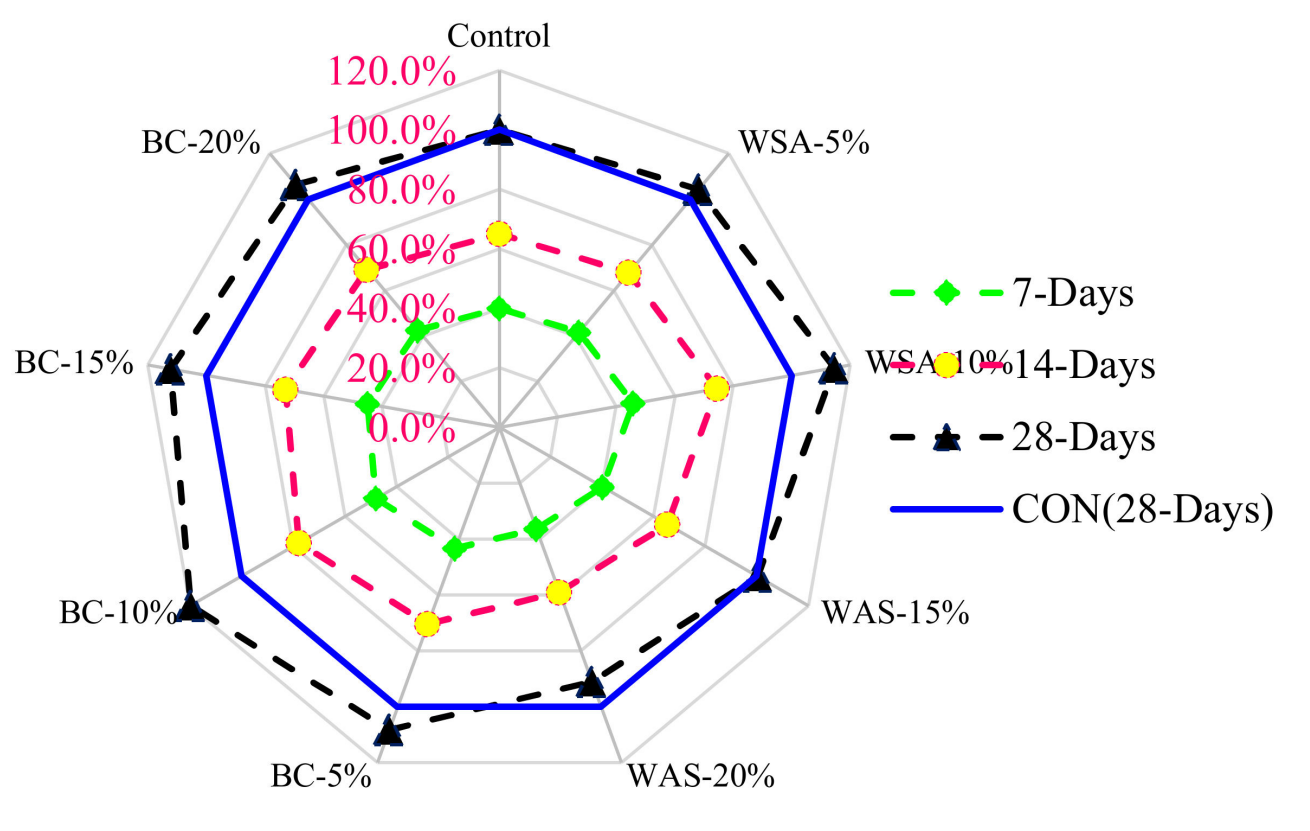

Figure 8. Relative analysis of compressive strength.

On day 7 of curing, compressive strength was about $55 \%$ less than that of the control (28 days) at 10\% substitution with WSA (optimum dosage). As compared to the control, $15 \%$ substitution with bentonite (optimum dosage) showed $57 \%$ less compressive strength. On day 14 of curing, compressive strength was about $25 \%$ less than that of the control (28 days) at $10 \%$ substitution with WSA (optimum dosage). As compared to the control, $15 \%$ substitution with bentonite (optimum dosage) showed 28\% less compressive strength. On day 28 of curing, compressive strength was about $15 \%$ higher than that of the control (28 days) at $10 \%$ substitution with WSA (optimum dosage). As compare to the control, 15\% substitution with bentonite (optimum dosage) showed $12 \%$ higher compressive strength.

Response surface methodology is a statistical tool, and its main purpose is to optimize a response or output which can be influenced by several factors or input variables. When there is more than one response, it is important to identify the combined optimum dosage of both materials that does not optimize only one response [31]. In this research, Minitab software was used to develop a 3D response surface for the combined effects of the transverse strength of BC and WSA.

To evaluate the optimum dosages of WSA and BC in SCC, the 3D response surface was converted into a contour plot with $14 \%$ BC and $12 \%$ WSA providing a compressive strength of $52 \mathrm{Mpa}$, as shown in Figures 9 and 10. To validate the calculated value of the statistical models for the compressive strength of concrete, similar dosages of BC and WSA $(14 \%, 12 \%)$ were casted and experimentally tested in the laboratory. It can be observed that that the experimental value closely agreed with the predicted value, which validated the calculated response of the surface models. 


\section{Surface Plot of Strength vs BC, WSA}

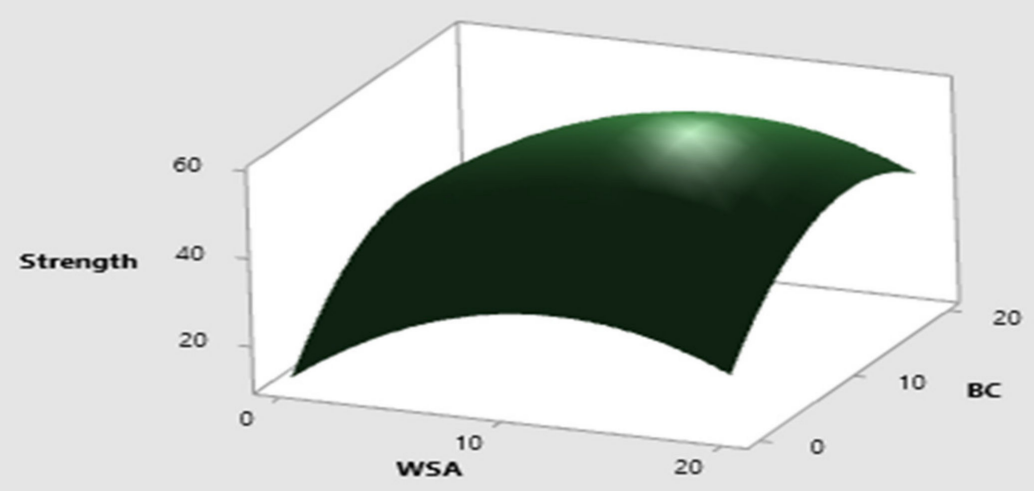

Figure 9. 3D response surface for compressive strength.

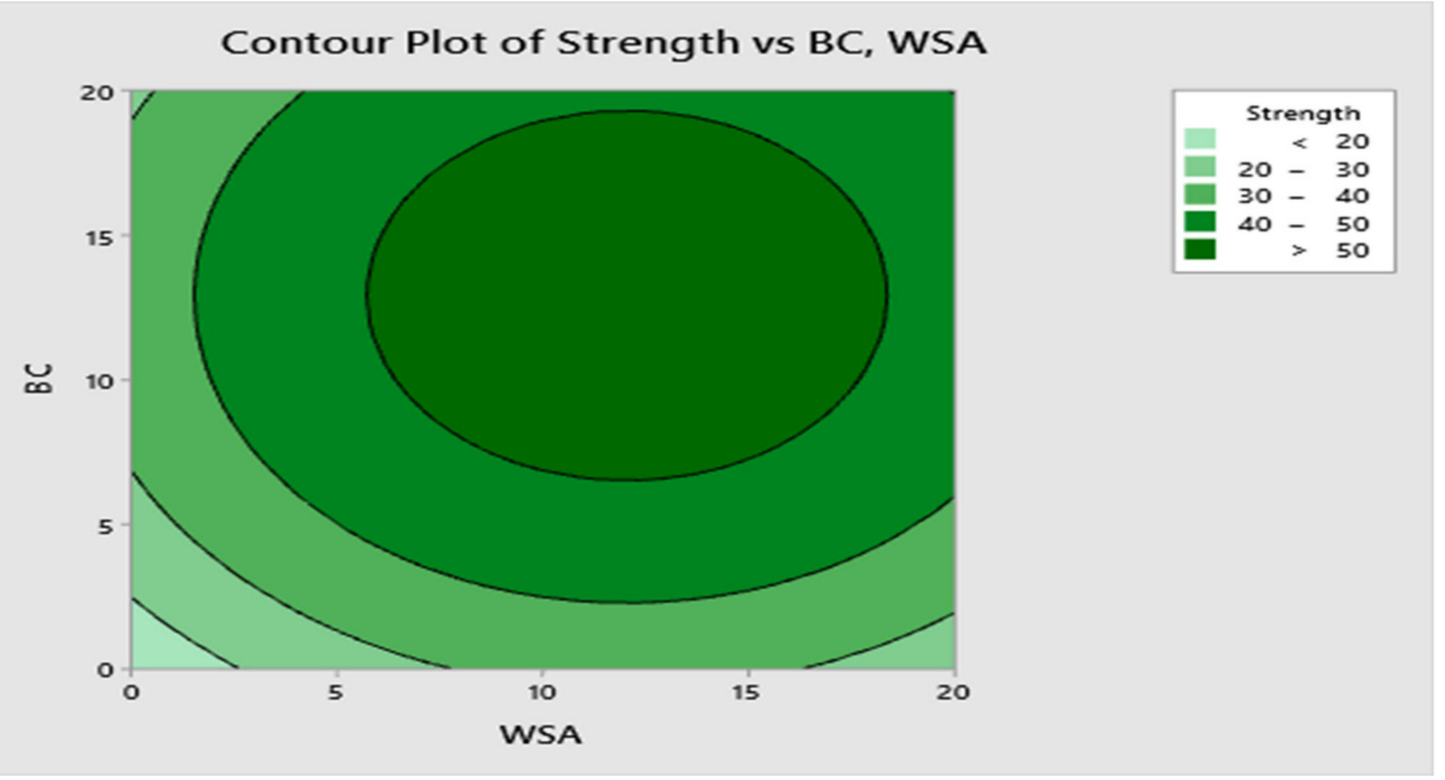

Figure 10. Contour plot for compressive strength.

\subsection{Split Tensile Strength}

This property of concrete describes the strength of concrete in tension. Cylindrical samples were longitudinally subjected to a compressive testing machine after curing, as shown in Figure 11. This is an indirect method to identify the tensile strength of concrete in which compressive load is applied until the specimen fails due to the development of tensile force in concrete. In this method, the cylindrical samples are split across a vertical diameter. The direct method cannot be used because it is impossible to apply pure axial load, as there is the possibility that such load may apply some irregularities on the specimen of concrete. 


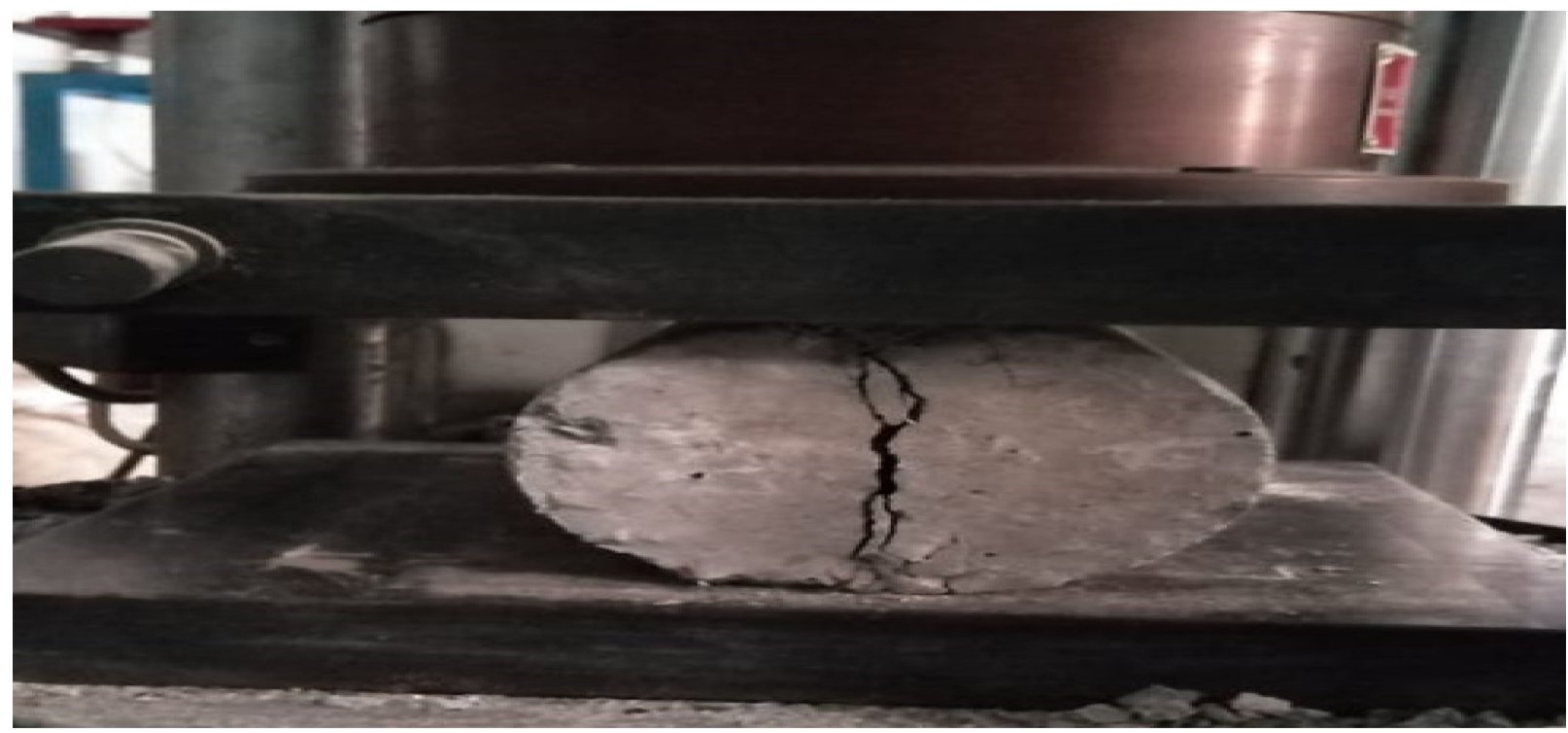

Figure 11. Split tensile strength setup.

Figure 12 shows the split tensile strength of varying dosages of wheat straw ash and bentonite clay. Similar to compressive strength, split tensile strength increased as the substitution percentage of wheat straw ash increased by up to $10 \%$ of the weight of the cement, and then it decreased gradually. It was also observed that the split strength increased with the incorporation of wheat straw ash (WSA) [25]. The highest split tensile strength was obtained at a $10 \%$ dosage of WSA as compared to blank or reference concrete. However, beyond the $10 \%$ dosage, the split tensile strength decreased. The positive effect on split tensile strength is due to the pozzolanic reaction of wheat straw ash (WSA) producing additional cementitious compounds $[17,25,29,30]$. The additional binder produced by the wheat straw ash (WSA) reaction with available lime allows wheat straw ash (WSA) concrete to continue to gain strength over time. However, at a higher dosage (WSA 20\%), the compaction process became more difficult due to the lack of workability, which resulted in porous concrete with lower strength [25].

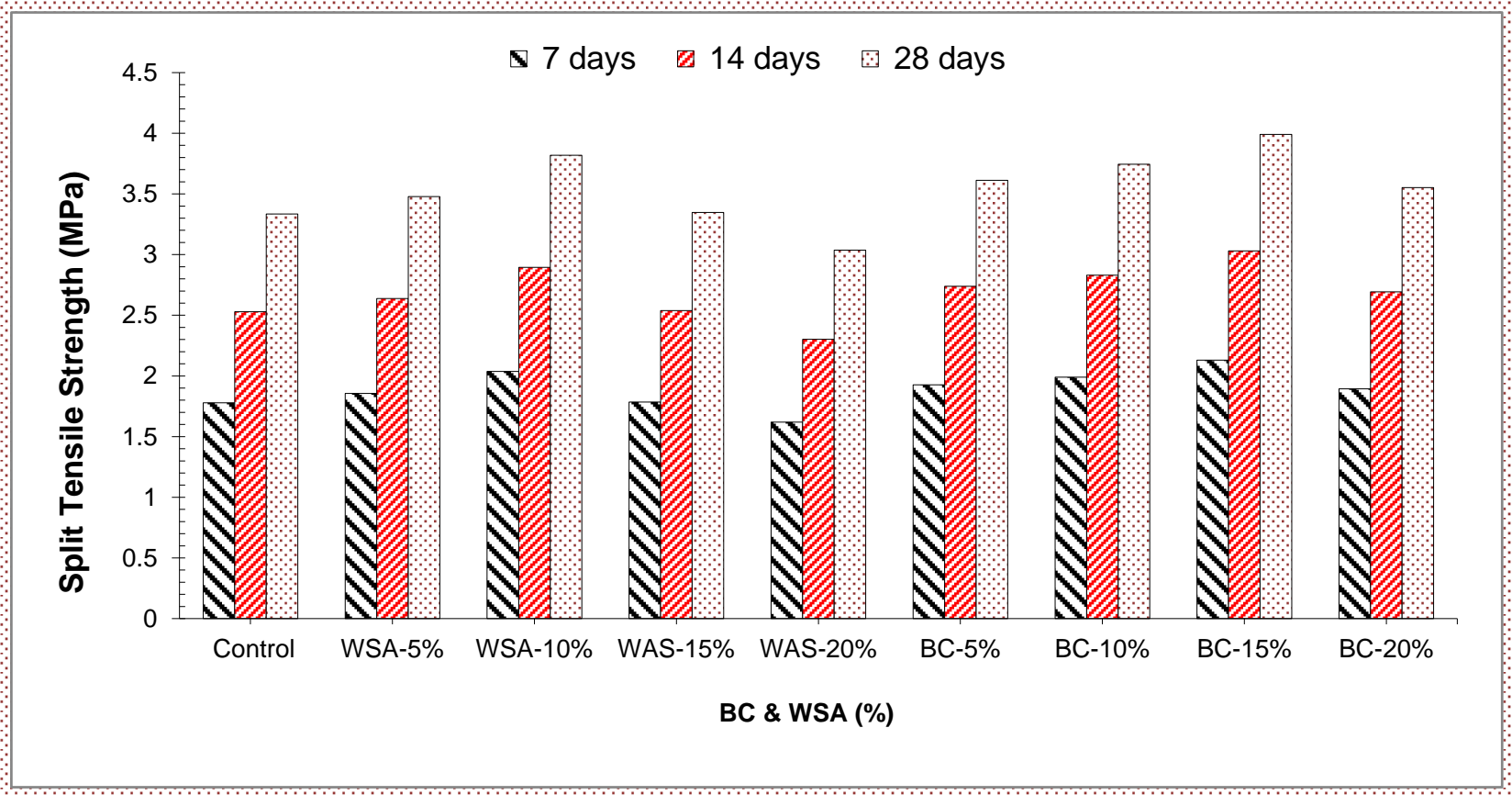

Figure 12. Split tensile strength results. 
Regarding bentonite clay $(\mathrm{BC})$, like compressive strength, split tensile strength increased as the substitution percentage of bentonite clay (BC) increased by up to $15 \%$ of the weight of the cement, and then it decrease gradually, as shown in Figure 12. It was also observed that the split strength increased with the incorporation of bentonite clay (BC) [9]. The highest split tensile strength was obtained at the $15 \%$ dosage of bentonite clay (BC) as compared to blank or reference concrete. However, beyond the $15 \%$ dosage, the split tensile strength decreased. The positive effect on split tensile strength is due to the pozzolanic reaction of bentonite clay (BC) [9] producing additional cementitious compounds. The additional binder produced by the bentonite clay $(\mathrm{BC})$ reaction with available lime allows bentonite clay $(\mathrm{BC})$ concrete to continue to gain spilt tensile strength over time. However, at the higher dosage bentonite clay (BC), the compaction process became more difficult due to the lack of workability, which resulted in porous concrete with lower strength [27].

However, at higher dosages of BC and WSA ( $20 \%$ of the weight of the cement), the strength of the concrete began to gradually decrease. This is due to the dilution effect, i.e., a smaller amount of $\mathrm{CH}$ (calcium hydroxide) available to react with $\mathrm{SiO}_{2}$ (present in $\mathrm{BC}$ and WSA) in order to form C-S-H (calcium-silicate-hydrate). Excess silica causes the alkali silica reaction, and results show that strength begins to decrease [27]. Moreover, at higher dosages of BC and WSA ( $20 \%$ of the weight of the cement), the workability also decreases; thus, further efforts regarding compaction are required to reduce void content that results in porous concrete with less strength [25].

A relative analysis was also carried out in which the 28-day split tensile strength of the control mix was considered the reference mix, and from this, different mixes of varying percentages of wheat straw ash (WSA) and bentonite clay (BC) were compared, as shown in Figure 13.

On day 7 day of curing, split tensile strength was about 39\% less than that of the control (28 days) at $10 \%$ substitution with WSA (optimum dosage). As compared to the control, $15 \%$ substitution with bentonite (optimum dosage) showed $42 \%$ less split tensile strength. On day 14 of curing, split tensile strength was about $14 \%$ less than that of the control (28 days) at $10 \%$ substitution with WSA (optimum dosage). As compared to the control, $15 \%$ substitution with bentonite (optimum dosage) showed $15 \%$ less split tensile strength. On day 28 day of curing, split tensile strength was about $14 \%$ higher than that of the control (28 days) at 10\% substitution with WSA (optimum dosage). As compared to the control, $15 \%$ substitution with bentonite (optimum dosage) showed $13 \%$ higher split tensile strength.

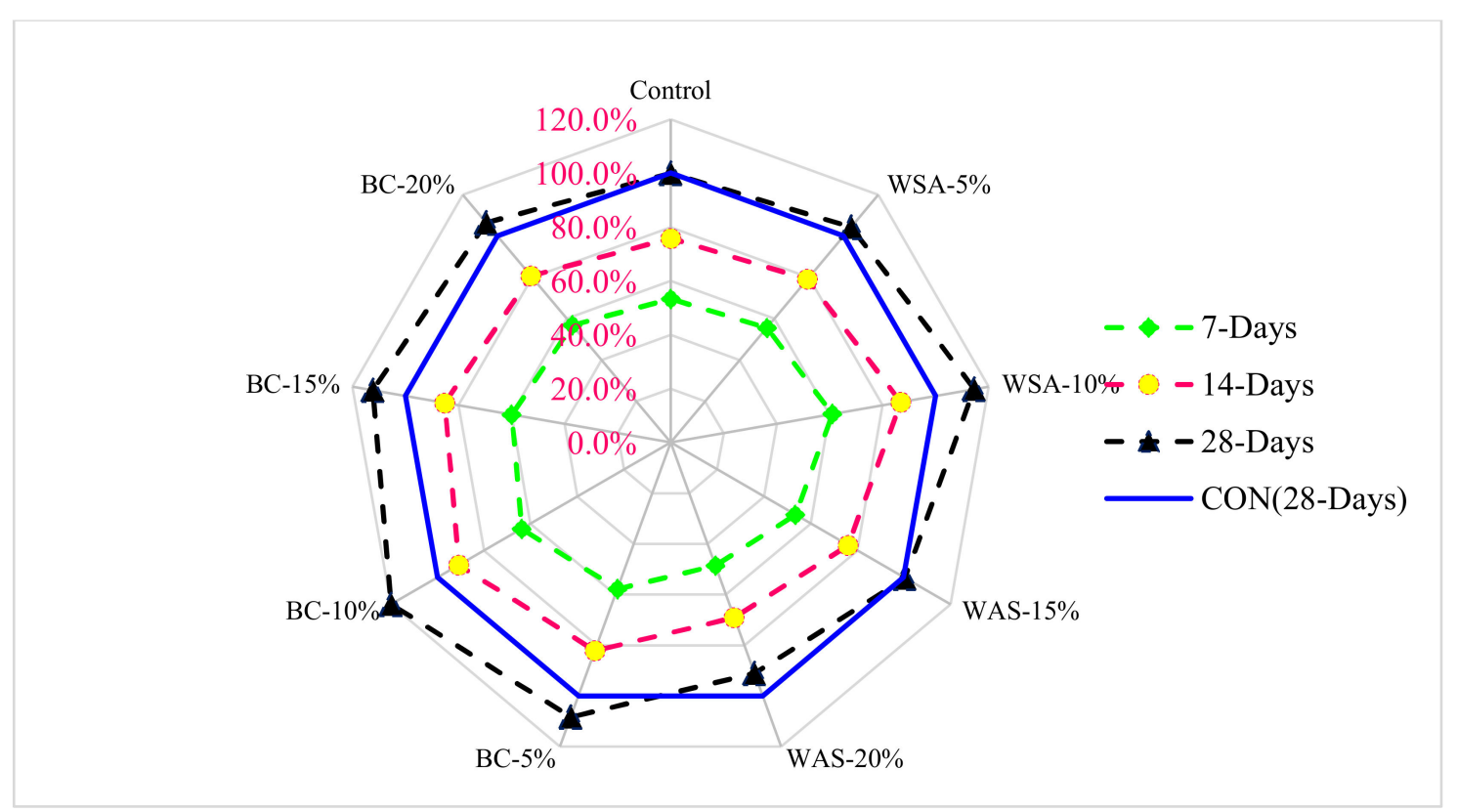

Figure 13. Relative analysis of split tensile strength. 
To evaluate the optimum dosage of WSA and BC for split tensile strength in SCC, $14 \% \mathrm{BC}$ and $12 \%$ WSA were selected from the contour plot, providing split tensile strength of 6.4 Mpa, as shown in Figures 14 and 15. To validate the calculated value of the statistical models for the split tensile strength of the concrete, similar dosages of BC and WSA (14\% and $12 \%$ ) were casted and experimentally tested in the laboratory on the same days. It can be observed that that the experimental value closely agreed with the predicted value, which validates the calculated response surface models.

\section{Surface Plot of Strength vs BC, WSA}

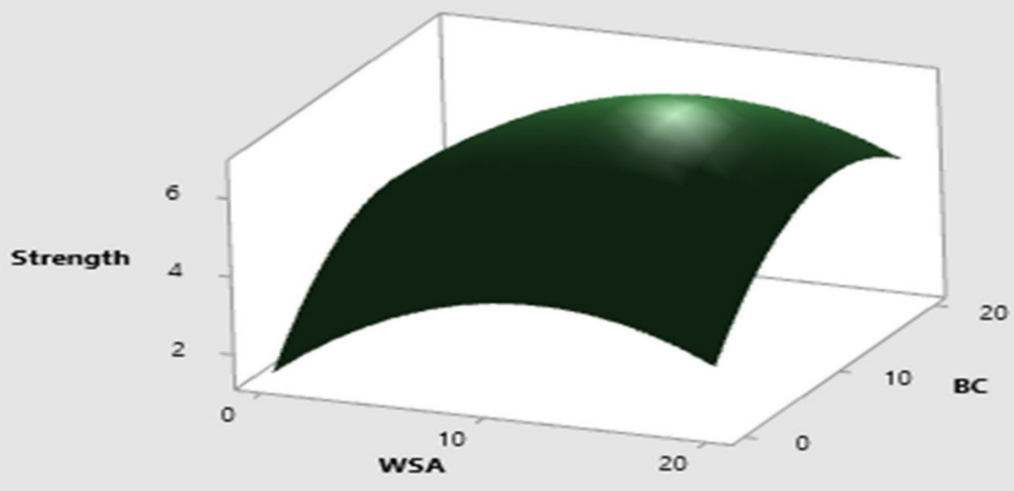

Figure 14. 3D response surface for split tensile strength.

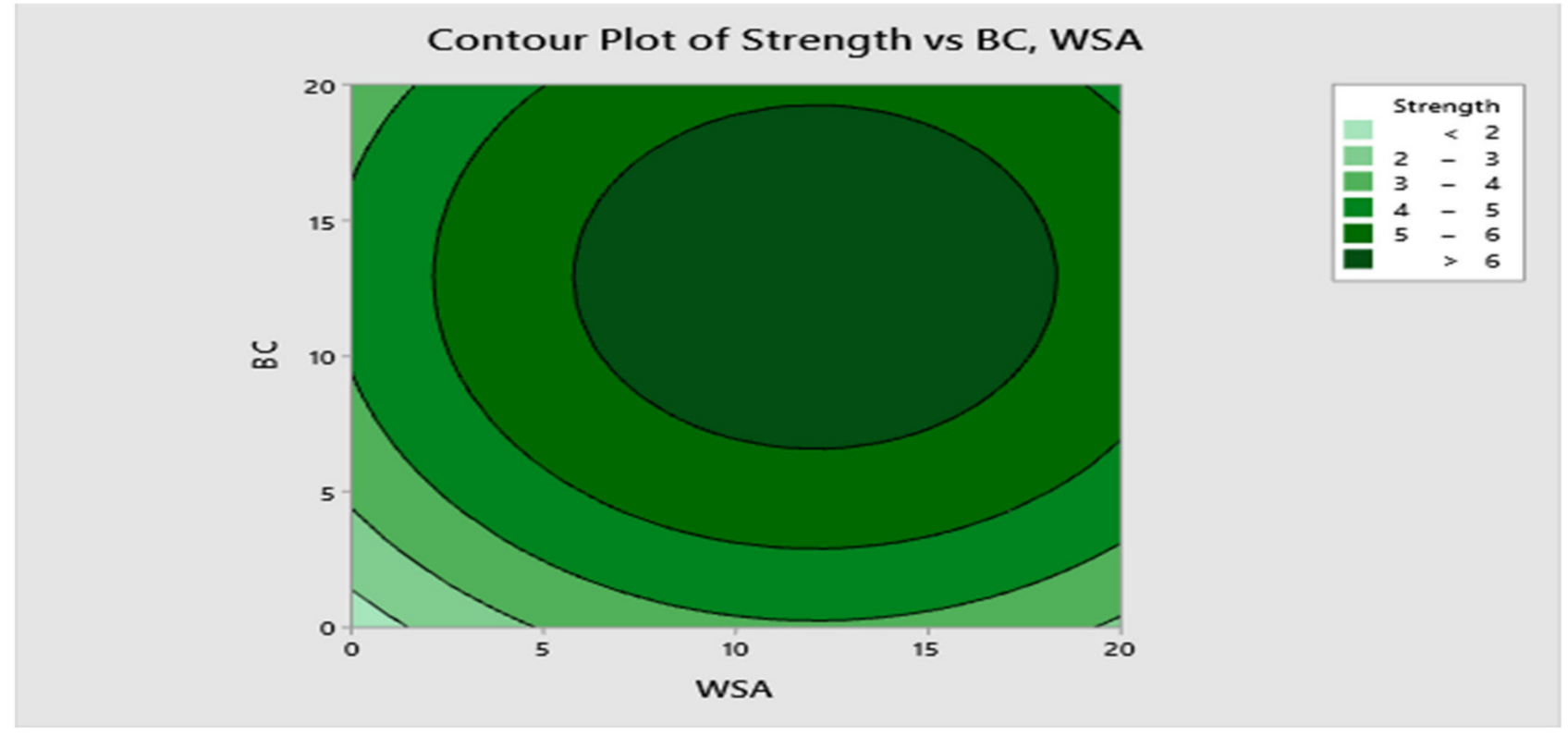

Figure 15. Contour plot for split tensile strength.

\section{Conclusions}

In this research, bentonite clay (BC) and wheat straw ash (WSA) were replaced in proportions of $0 \%, 5.0 \%, 10 \%, 15 \%$, and $20 \%$ in relation to the weight of the cement. Based on the experimental works, the following conclusion can be made: 
- Flowability and passing ability decreased as the percentage of bentonite clay (BC) and wheat straw ash (WSA) increased. This due to the particle shape and the larger.

- Surface area of bentonite clay (BC) and wheat straw ash (WSA) resulting in an increase in the internal friction between the aggregate particles and more paste being required for lubrication; as result, the filling and passing abilities of the SCC decrease. However, all of the mixes show filling and passing ability, with the limit defined by the technical specification for SCC.

- $\quad$ Strength (compressive and split tensile) increased as the substitution percentage of bentonite clay (BC) increased by up to $15 \%$, and then it decreased when compared to the control mix. In the case of wheat straw ash (WSA), the strength increased with up to $10 \%$ substitution and then decreased when compared to the control mix. This is due to micro filling voids in the aggregate as well as the pozzolanic activity of bentonite clay $(\mathrm{BC})$ and wheat straw ash (WSA).

- Based on the results, the predicted value obtained from the statistical analysis and the experimental value were comparable.

- The highest strength was obtained at the ratio of $14 \%$ WSA and $12 \%$ BC, respectively, and it had a maximum compressive strength of $52 \mathrm{Mpa}$, which is almost $93 \%$ higher than that of reference concrete. Therefore, $14 \%$ WSA and 12\% BC were optimum dosages for combined substitution.

Author Contributions: Conceptualization, J.A.; Methodology, J.A. and O.Z.; Supervision, F.A. and R.A.; Visualization, R.F.T.; Resources, M.F.J. and A.M.; Formal analysis, O.Z. and M.S.K.N.; Original draft preparation, J.A. and O.Z.; Writing-review and editing, F.A. and R.A. All authors have read and agreed to the published version of the manuscript.

Funding: This research received no external funding.

Institutional Review Board Statement: Not applicable.

Informed Consent Statement: Not applicable.

Data Availability Statement: The data presented in this study are available on request from the corresponding author.

Conflicts of Interest: The authors declare no conflict of interest.

\section{References}

1. EFNARC. Specification and Guidelines for Self-Compacting Concrete; Association House: London, UK, 2002; Volume 32 , p. 34.

2. Okamura, H. Self-compacting high-performance concrete. Concr. Int. 1997, 19, 50-54.

3. Ozawa, K. High-performance concrete based on the durability design of concrete structures. In Proceedings of the Second East Asia-Pacific Conference on Structural Engineering and Construction, Chiang Mai, Thailand, 11-13 January 1989.

4. Sankh, A.C.; Biradar, P.M.; Naghathan, S.J.; Ishwargol, M.B. Recent trends in replacement of natural sand with different alternatives. In Proceedings of the International Conference on Advances in Engineering and Technology, Nagapattinam, India, 2-3 May 2014; pp. 59-66.

5. Isler, J.W. Assessment of Concrete Masonry Units Containing Aggregate Replacements of Waste Glass and Rubber Tire Particles. Master's Thesis, University of Colorado at Denver, Denver, CO, USA, 2012.

6. Benhelal, E.; Zahedi, G.; Shamsaei, E.; Bahadori, A. Global strategies and potentials to curb CO2 emissions in cement industry. J. Clean. Prod. 2013, 51, 142-161. [CrossRef]

7. World Business Council for Sustainable Development. The Cement Sustainability Initiative—Cement Industry Energy and CO 2 Performance: "Getting the Numbers Right"; WBCSD: Geneva, Switzerland, 2009.

8. Armstrong, T.; Bal, M.; Bell, P.; Fernandes, J.; Starbuck, S. The Global Cement Report. Int. Cem. Rev. 2013, $13,372$.

9. Mirza, J.; Riaz, M.; Naseer, A.; Rehman, F.; Khan, A.; Ali, Q. Pakistani bentonite in mortars and concrete as low cost construction material. Appl. Clay Sci. 2009, 45, 220-226. [CrossRef]

10. Assefa, S.; Dessalegn, M. Production of Lightweight Concrete Using Corncob Ash as Replacement of Cement in Concrete. Am. J. Civ. Eng. 2009, 7, 17-20. [CrossRef]

11. Thomas, J.; Thaickavil, N.N.; Syamala, T.N. Cement Replacement Materials for Sustainable Concrete. In Green Buildings and Sustainable Engineering; Springer: Singapore, 2019; pp. 387-403.

12. Khan, M.I.; Mourad, S.M.; Charif, A. Utilization of Supplementary Cementitious Materials in HPC: From rheology to pore structure. KSCE J. Civ. Eng. 2017, 21, 889-899. [CrossRef] 
13. Bheel, N.; Meghwar, S.L.; Sohu, S.; Khoso, A.R.; Kumar, A.; Shaikh, Z.H. Experimental Study on Recycled Concrete Aggregates with Rice Husk Ash as Partial Cement Replacement. Civ. Eng. J. 2018, 4, 2305-2314. [CrossRef]

14. Ahmad, Z.; Siddiqi, R.A. Minerals and rocks for industry. Int. J. Rock Mech. Min. Sci. Geomech. Abstr. 1995, 3, 370A-371A.

15. Kaur, G.; Siddique, R.; Rajor, A. Properties of concrete containing fungal treated waste foundry sand. Constr. Build. Mater. 2012, 29, 82-87. [CrossRef]

16. Mo, K.H.; Alengaram, U.J.; Jumaat, M.Z.; Yap, S.P.; Lee, S.C. Green concrete partially comprised of farming waste residues: A review. J. Clean. Prod. 2016, 117, 122-138. [CrossRef]

17. Biricik, H.; Akoz, F.; Berktay, I.; Tulgar, A.N. Study of pozzolanic properties of wheat straw ash. Cem. Concr. Res. 1999, 29, 637-643. [CrossRef]

18. Memon, S.A.; Arsalan, R.; Khan, S.; Lo, T.Y. Utilization of Pakistani bentonite as partial replacement of cement in concrete. Constr. Build. Mater. 2012, 30, 237-242. [CrossRef]

19. Stutzman, P. Powder diffraction analysis of hydraulic cements: ASTM Rietveld round-robin results on precision. Powder Diffr. 2005, 20, 97-100. [CrossRef]

20. ENTS 934-2. Admixtures for Concrete, Mortar and Grout-Part 2: Concrete Admixtures; Definitions, Requirements, Conformity, Marking and Labelling; British Standard Institution: London, UK, 2009.

21. ASTMC 494/C 494M-01. Standard Specification for Chemical Admixtures for Concrete; ASTM International: West Conshohocken, PA, USA, 2019; p. 15.

22. C39/C39MA. Standard Test Method for Compressive Strength of Cylindrical Concrete Specimens; Annual British ASTM Standards; British Standard Institution: London, UK, 2003.

23. C496-71A. Standard Test Method for Splitting Tensile Strength of Cylindrical Concrete Specimens; British Standard Institution: London, UK, 1976.

24. ASTM C39/C39M-12. Standard Test Method for Compressive Strength of Cylindrical Concrete Specimens; ASTM International: West Conshohocken, PA, USA, 2012. [CrossRef]

25. Al-Akhras, N.M.; Abu-Alfoul, B.A. Effect of wheat straw ash on mechanical properties of autoclaved mortar. Cem. Concr. Res. 2002, 32, 859-863. [CrossRef]

26. Van Olphen, H. An Introduction to Clay Colloid Chemistry, for Clay Technologists, Geologists, and Soil Scientists; John Wiley \& Sons: Somerset, NJ, USA, 1977.

27. Lima-Guerra, D.J.; Mello, I.; Resende, R.; Silva, R. Use of bentonite and organobentonite as alternatives of partial substitution of cement in concrete manufacturing. Int. J. Concr. Struct. Mater. 2014, 8, 15-26. [CrossRef]

28. Hamzah, A.F.; Ibrahim, M.N.; Jamaluddin, N.; Jaya, R.P.; Arshad, M.F.; Abidin, N.E.Z. Fresh characteristic and mechanical compressive strength development of self-compacting concrete integrating coal bottom ash as partial fine aggregates replacement. Int. J. Mech. Mechatron. Eng. 2015, 15, 61-67.

29. Iqbal, S.; Ali, A.; Holschemacher, K.; Ribakov, Y.; Bier, T.A. Effect of fly ash on properties of self-compacting high strength lightweight concrete. Period. Polytech. Civ. Eng. 2017, 61, 81-87. [CrossRef]

30. Qudoos, A.; Kim, H.G.; Ryou, J.-S. Effect of mechanical processing on the pozzolanic efficiency and the microstructure development of wheat straw ash blended cement composites. Constr. Build. Mater. 2018, 193, 481-490. [CrossRef]

31. Oehlert, G.W. Design and Analysis of Experiments: Response Surface Design; W.H. Freeman Company: New York, NY, USA, 2000; pp. 509-542. 